\title{
PHYSIOLOGICAL RESPONSES TO HIGH EXOGENOUS SUCROSE IN TUBER INDUCTION OF POTATO IN VITRO
}

\author{
Xueqin $H^{*}$, Meilian MENG \\ Inner Mongolia Agricultural University, Agronomy Faculty, Hohhot, CHINA \\ *Corresponding author: xueqinhe2013@163.com \\ Received: 31.11 .2015
}

\begin{abstract}
Microtubers are valuable tools to be used in the researches of potato. Among the factors sucrose is the most critical stimulus for potato microtuber production in vitro. The aim of our study was to define whether only sucrose was enough to induce the tuber and how it impacted on physiological responses in potato in vitro. Among sucrose concentrations chosen 80 and $100 \mathrm{~g} / \mathrm{l}$ sucrose could induce maximum tubers in three cultivars of Solanum tuberosum L., Atlantic, Desiree and 851 in vitro at $22^{\circ} \mathrm{C}$ under $16-\mathrm{h}$ photoperiod. Meanwhile tuber induction percentage showed no difference in MS with 80 and $100 \mathrm{~g} / \mathrm{l}$ sucrose among 0 , 16 and 24-h photoperiod and cuttings with no nodes induced no tubers in cv. Atlantic. Therefore, 80 or $100 \mathrm{~g} / \mathrm{l}$ of exogenous sucrose concentrations and cuttings with node were essential to in vitro tuber induction in potato. The endogenous sucrose content and acid invertase in induced cuttings were higher than corresponding tubers and dramatically increased with the increase of sucrose concentration in MS. Starch content was completely opposite to endogenous sucrose content and decreased with the increase of sucrose concentration in MS. Sucrose synthase (Susy) and sucrose phosphate synthase (SPS) accumulated only in tubers, but no significant differences of Susy and SPS were between $80 \mathrm{~g} / \mathrm{l}$ and $100 \mathrm{~g} / \mathrm{l}$ sucrose. In conclusion, high levels of exogenous sucrose resulted in a dramatic high gradient of endogenous sucrose content between inducing cuttings and the corresponding tubers, which was beneficial to trigger differential activity expression of sugar metabolizing enzymes and to accumulate starch in tubers in vitro.
\end{abstract}

Keywords: Microtuber; potato; sucrose; sugar metabolic enzymes

\section{INTRODUCTION}

Microtubers were used in seed potato (Solanum tuberosum L.) production (Öztürk \& Yildirim, 2010) and potato germplasm conservation (Lizarraga, 1989), as well as in analyzing of physiological and biochemical metabolism (Cenzano et al., 2006, 2008; Raíces et al., 2003a) and gene expression associated with tuber formation and growth (Gargantini et al., 2009; Raíces et al., 2003c). It also served as a source for studies of genetic transformation (Gargantini et al., 2009; Si et al., 2008).

Since Barker (1953) first used etiolated sprouts to induce potato tubers in a medium containing $80 \mathrm{~g} / 1$ sucrose, high sucrose ranging from 60 to $90 \mathrm{~g} / \mathrm{l}$ and different explants including apical/uppermost nodal sections of the shoot and nodal segments/cuttings were used to induce in vitro tubers under a short photoperiod from 8 to $10 \mathrm{~h}$ or in the dark (Altindal \& Karadoğan, 2010; Aslam et al., 2011; Dhital \& Lim, 2012; Hoque 2010; Hussain et al., 2006; Motallebi-Azar et al., 2013; Servet et al., 2000). Wang \& $\mathrm{Hu}$ (1982) and Ewing \& Struik (1992) considered sucrose may be the most critical stimulus for potato microtuber production in vitro.
During the stages of potato tuber formation developing tubers become the largest sinks accompanying increased cell division and expansion and a massive deposition of starch (Gargantini et al., 2009; Prat et al., 1990; Visser et al., 1994). Khuri \& Moorby (1995) found that the translocation and usage of sucrose was faster than the other sugars in the tubering plantlet in vitro. A large proportion of sucrose taken up into sink-tissue was converted to starch in rapidly growing potato tubers (Oparka et al., 1990; Wright \& Oparka, 1989). The accumulation of starch (Visser et al., 1994) and the quantity and composition of soluble sugars (Davies, 1984) associated with a tuber undergo significant changes. High sucrose levels increased Susy in the potato in culture medium (Sowokinos \& Varns, 1992). Sucrose can be hydrolyzed by either invertases or Susy in most plants (Koch, 2004; Kruger 1990). The reaction catalyzed by invertase is highly irreversible and by Susy is freely reversible in the direction of sucrose degradation (Avigad 1982; Geigenberger \& Stitt, 1993; Kruger 1990; Morell \& Copeland, 1985). 
Sucrose was considered to be the most critical stimulus for potato microtuber production in vitro (Ewing \& Struik, 1992; Wang \& Hu, 1982). The objective of the present work was to define whether sucrose was the only essential factor for tuber induction and how it influenced sugar metabolic activities in potatoes in vitro. Our results will be facilitated to develop strategies for optimized crop management for high microtuber yield and to save cost in vitro and in the green house.

\section{MATERIALS AND METHODS}

\section{Plant material}

Stem cuttings were taken from 4 week microplants of potato (Solanum tuberosum L.) cultivars such as Atlantic, Desiree and 851 in vitro at $22{ }^{\circ} \mathrm{C}$ under 16 -h photoperiod $\left(124 \mu \mathrm{mol} / \mathrm{m}^{2} \mathrm{~s}^{1}\right)$. All stem cuttings were prepared from middle nodes of the microplants.

\section{In vitro Tuberization}

Two-node cuttings of potato cultivars were placed vertically on MS (Murashige \& Skoog, 1962) medium containing 50,60, 80, 100 and $120 \mathrm{~g} / \mathrm{l}^{-1}$ sucrose at $22^{\circ} \mathrm{C}$ under 16 -h photoperiod. From the $7^{\text {th }}$ day induced tubers were recorded every 2 days until the $19^{\text {th }}$ day. After determining the optimal sucrose concentration in MS the effects of photoperiods ( 0,16 and $24 \mathrm{~h}$ ) and node numbers of the cuttings (0, 1 and 2 nodes) were studied, respectively. Tuber induction percentage (TIP) was calculated as a percentage on the basis of total induced cuttings.

Induced cuttings and corresponding tubers were separately harvested in MS with $80 \mathrm{~g} / \mathrm{l}$ and $100 \mathrm{~g} / \mathrm{l}$ sucrose at $22^{\circ} \mathrm{C}$ under 16 -h photoperiod on the $19^{\text {th }}$ day and were used in the following studies.

\section{Content of sucrose and starch}

For determining sucrose and starch content $100 \mathrm{mg}$ of fresh tissue were ground and extracted in $80 \%(\mathrm{v} / \mathrm{v})$ ethanol. The extract was centrifuged at $4000 \mathrm{~g}$ for $5 \mathrm{~min}$ and its supernatant fraction was evaporated, and then the residues were suspended in purified water and stored at $-20^{\circ} \mathrm{C}$ to use. The pellets free from sugar were extracted with $80 \%$ ethanol again, and then were dried and stored for starch extraction.

Sucrose was determined according to Wang (2000) with a $2.3 \mathrm{ml}$ reaction mixture including $0.1 \mathrm{ml}$ of extract, $0.2 \mathrm{mM} \mathrm{NaOH}, 6.2 \mathrm{M} \mathrm{HCl}$ and $2 \mathrm{mM}$ o-Dihydroxybenzene. Readings were made at $480 \mathrm{~nm}$. Sucrose content was estimated using a sucrose calibration curve.

Starch was based on Hovenkamp-Hermelink et al. (1988) with modification. Starch was extracted from the dried sugar-free residue with $5 \mathrm{M} \mathrm{Ca}\left(\mathrm{NO}_{3}\right)_{2}$ at $100{ }^{\circ} \mathrm{C}$ for $5 \mathrm{~min}$, and the extract centrifuged at $3000 \mathrm{~g}$ for $5 \mathrm{~min}$. $\mathrm{I}_{2}-\mathrm{KI}$ staining was achieved by mixing $5 \mathrm{ml}$ of supernatant and $5 \mathrm{ml}$ of $20 \mathrm{mM} \mathrm{KI}$ and $6.5 \mathrm{mM} \mathrm{I}_{2}$. Absorbencies were measured immediately after mixing at $620 \mathrm{~nm}$. Starch content was estimated using a glucose calibration curve.

\section{Sugar metabolism enzyme}

One hundred mg of fresh tissue was ground at $4{ }^{\circ} \mathrm{C}$ and extracted with an extraction buffer including $50 \mathrm{mM}$ HEPES-KOH (pH 7.4), $5 \mathrm{mM} \mathrm{MgC1}{ }_{2}, 1 \mathrm{mM}$ EDTA, $5 \mathrm{mM}$ DTT and $2 \%$ insoluble PVP. The extract was centrifuged at $16,000 \mathrm{~g}$ at $4^{\circ} \mathrm{C}$ for $10 \mathrm{~min}$ and the supernatant was used in enzyme activities analysis. The reaction with heat-inactivated enzyme preparation was used as control.

Soluble acid invertase (E.C. 3.2.1.26) was measured based on Geigenberger \& Stitt (1993) with modification. The reaction mixture contained $0.1 \mathrm{ml}$ supernatant, $100 \mathrm{mM}$ sucrose, $50 \mathrm{mM}$ sodium citrate $(\mathrm{pH} 5.0)$, and $50 \mathrm{mM} \mathrm{KCl}$. Glucose formed was determined as described above.

Sucrose synthase (Susy: E.C.2.4.1.13) and sucrose-6-phosphate synthase (SPS: E.C.2.4.1.14) were measured according to Zhu et al. (1997). The Susy assay solution was $20 \mathrm{mM}$ fructose, $20 \mathrm{mM}$ UDP-glucose, $1 \mathrm{mM}$ $\mathrm{MgCl}_{2}$ and 50mM HEPES-KOH (pH 7.0), and the SPS assay solution included $100 \mathrm{mM}$ Hepes (pH 7.5), 20mM glucose-6-phosphate, $20 \mathrm{mM}$ frucrose-6-phosphate, $20 \mathrm{mM}$ UDP-glucose, $1 \mathrm{mM} \mathrm{MgCl}_{2}$, and $1 \mathrm{mM}$ EDTA. Sucrose produced by these reactions was assayed using the anthrone assay.

Protein contents were determined according to the Bradford (1976) method.

\section{Statistical analysis}

Every treatment was repeated 3 times and one replicate included two $100 \mathrm{ml}$-flasks with 10 cuttings per flask. This experiment was repeated twice in laboratory of Inner Mongolian Agricultural University, Hohhot in 2012.

Completely randomized blocks statistical design and SAS9.0 were used for comparing the means. The significance of differences between the variables was taken according to LSD test at $P \leq 0.05$.

\section{RESULTS}

\section{Defining optimal concentration of exogenous sucrose on tuber induction in vitro}

Different concentrations of exogenous sucrose in MS had different TIPs in Solanum tuberosum L. cv. Atlantic. Cuttings dried early and no tuber appeared in MS with $120 \mathrm{~g} / \mathrm{l}$ sucrose. The TIPs from MS with 80 and $100 \mathrm{~g} / \mathrm{l}$ sucrose were much higher than 50 and $60 \mathrm{~g} / \mathrm{l}$ sucrose, but the TIPs between 80 and $100 \mathrm{~g} / \mathrm{l}$ sucrose had no significant difference during the induction period except on the $11^{\text {th }}$ day (Figure 1). Although the TIP, diameter and fresh weight of induced tubers by $80 \mathrm{~g} / \mathrm{l}$ sucrose were higher than those by $100 \mathrm{~g} / \mathrm{l}$ sucrose on the $19^{\text {th }}$ day, no significance was detected (Table 1). The same results were obtained for the same experiments in potato cultivars, 851 and Desiree and the average tuber number per cutting of $80 \mathrm{~g} / \mathrm{l}$ and $100 \mathrm{~g} / \mathrm{l}$ sucrose were listed in Table 2 . The results suggested that $80 \mathrm{~g} / \mathrm{l}$ and $100 \mathrm{~g} / \mathrm{l}$ sucrose had the same effect and were better than $50 \mathrm{~g} / \mathrm{l}$ and $60 \mathrm{~g} / \mathrm{l}$ sucrose on tuber induction in different potato cultivars in vitro. 


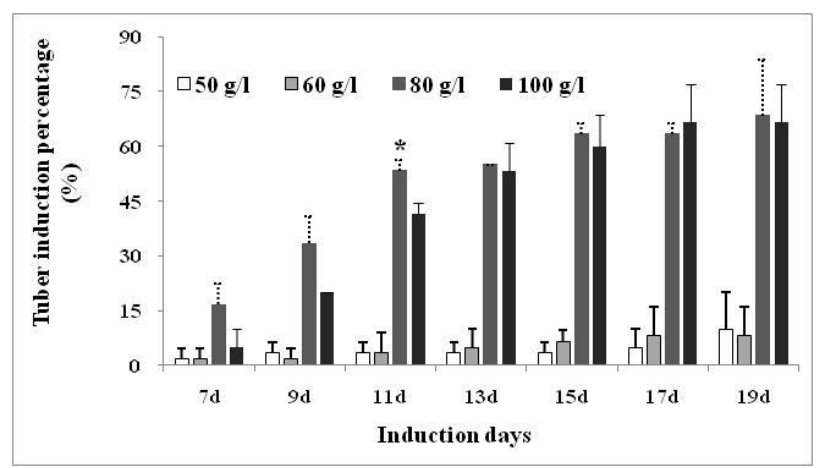

Figure1. Tuber induction percentage in MS with different concentrations of exogenous sucrose in Solanum tuberosum L. cv. Atlantic (* indicate differences within the group at 0.05 level).
Effect of photoperiod on tuber induction in MS with high sucrose in Solanum tuberosum L. cv. Atlantic

The TIPs of $80 \mathrm{~g} / \mathrm{l}$ sucrose under 0,16 and 24-h photoperiod were $70.0 \%, 68.3 \%$ and $78.3 \%$, which were higher than $100 \mathrm{~g} / \mathrm{l}$ sucrose, respectively, but the difference was not significant except under 24-h photoperiod (Figure 2, 3). Similarly, no significant differences were in MS with same sucrose concentrations among different photoperiods. However, the germination rates of tubers induced under 16-h light were higher than those under 0 -h light (Figure 4). Although the germination rates of tubers from $80 \mathrm{~g} / 1$ sucrose showed no dramatic differences with those from $100 \mathrm{~g} / \mathrm{l}$ sucrose under 16-h light the seedlings from the later were stronger than the former (Figure 5). Therefore, tubers induced in MS with high sucrose under 16-h photoperiod can be used for further studies.

Table1. Effect of $80 \mathrm{~g} / \mathrm{l}$ and $100 \mathrm{~g} / \mathrm{l}$ sucrose on induced tubers in Solanum tuberosum L. cv. Atlantic in vitro

\begin{tabular}{llll}
\hline & $\begin{array}{l}\text { Tubers caliber range } \\
(\mathbf{m m})\end{array}$ & $\begin{array}{l}\text { Average tuber } \\
\text { number/cutting }\end{array}$ & Fresh weight /tuber $(\mathbf{g})$ \\
\hline $80 \mathrm{~g} / \mathrm{l}$ & $2.002-6.010$ & $0.683 \pm 0.153$ & $0.043 \pm 0.001$ \\
$100 \mathrm{~g} / 1$ & $2.000-5.014$ & $0.667 \pm 0.104$ & $0.041 \pm 0.008$ \\
\hline
\end{tabular}

Table2. Average induced tubers of Solanum tuberosum L. cv., 851 and Desiree in MS with $80 \mathrm{~g} / 1$ and $100 \mathrm{~g} / 1$ sucrose

\begin{tabular}{lcc}
\hline & $\mathbf{8 0} \mathbf{g} / \mathbf{l}$ & $\mathbf{1 0 0} \mathbf{g} / \mathbf{l}$ \\
\hline cv. 851 & $0.523 \pm 0.127 \mathrm{a}$ & $0.586 \pm 0.143 \mathrm{a}$ \\
cv. Desiree & $0.625 \pm 0.215 \mathrm{a}$ & $0.750 \pm 0.238 \mathrm{a}$ \\
\hline
\end{tabular}

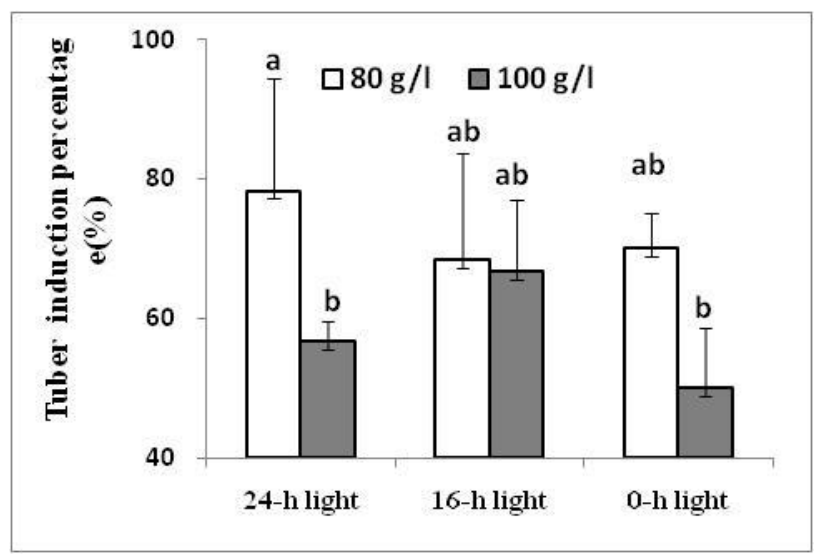

Figure 2. Tuber induction percentage under different conditions in Solanum tuberosum L. cv. Atlantic in vitro (Same letters indicate no differences within the group at 0.05 level).
Effect of node on tuber induction in MS with high sucrose in Solanum tuberosum L. cv. Atlantic

Cuttings with different node numbers were induced in MS with $80 \mathrm{~g} / \mathrm{l}$ and $100 \mathrm{~g} / \mathrm{l}$ sucrose under 16 -h photoperiod (Figure 6). The TIPs from 0,1 and 2 nodes were $0,43.3 \%$ and $75.0 \%$, respectively. In MS with $80 \mathrm{~g} / \mathrm{l}$ sucrose the TIP from 2 nodes was significantly higher than that from 1 node, but in MS with $100 \mathrm{~g} / \mathrm{l}$ sucrose there was no significant difference. Therefore, the cutting with 2 nodes was chosen to induce tuber in MS with high sucrose.

The influences of high sucrose in MS on contents of endogenous sucrose and starch of Solanum tuberosum $L$. cv. Atlantic in vitro

Cuttings with 2 nodes were induced in MS with $80 \mathrm{~g} / 1$ and $100 \mathrm{~g} / \mathrm{l}$ sucrose under $16-\mathrm{h}$ photoperiod. On the $19^{\text {th }}$ day the induced cuttings and corresponding tubers were harvested separately to study contents of endogenous sucrose and starch, as well as activities of sugar metabolism enzymes.

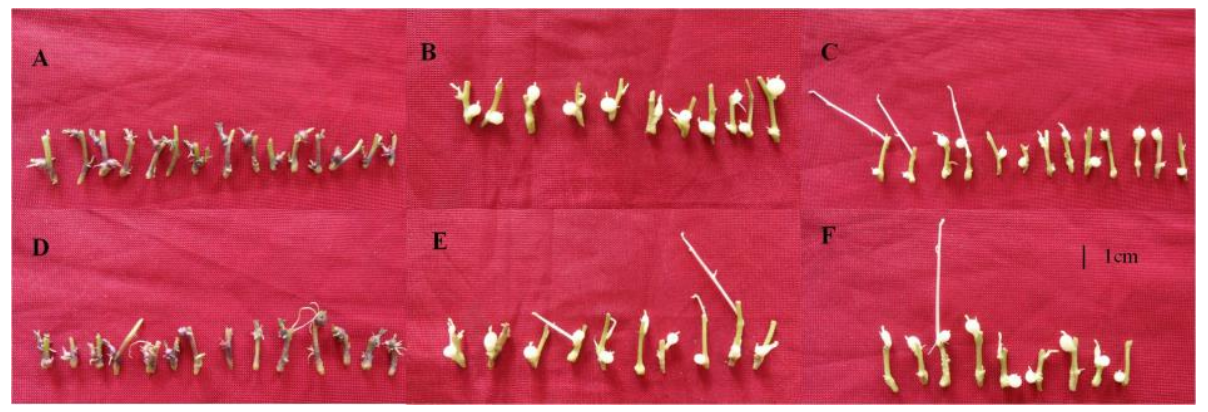

Figure 3. Tubers induced under different conditions in Solanum tuberosum L. cv. Atlantic in vitro. A-C: $80 \mathrm{~g} / \mathrm{l}$ under 24-h, 16-h and 0-h photoperiod; D-F: 100g/l under 24-h, 16-h and 0-h photoperiod. 


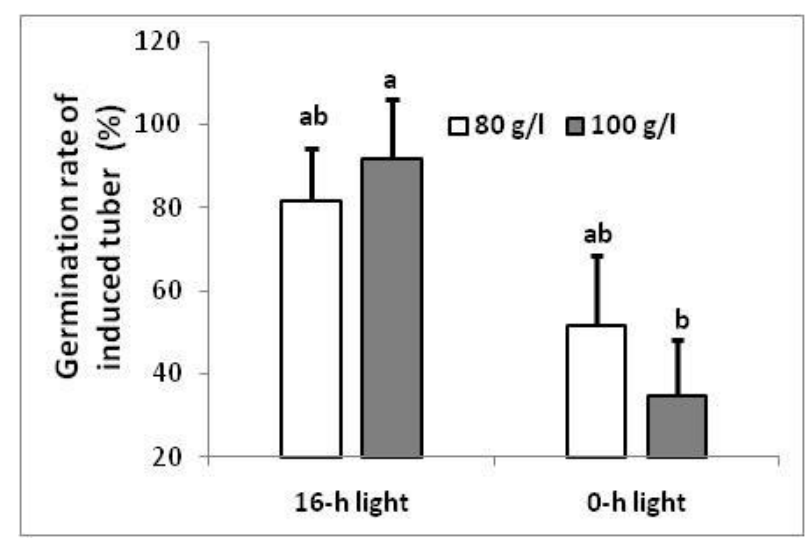

Figure 4. Germination rate of tuber induced under different conditions in Solanum tuberosum L. cv. Atlantic in vitro (Same letters indicate no differences within the group at 0.05 level)
Sucrose content in induced cuttings was significantly higher than that in corresponding tubers, but starch content were opposite in both sucrose concentrations (Figure 7). With the increase of sucrose concentration in MS endogenous sucrose content dramatically increased and starch content decreased in individually cuttings and tubers. Meanwhile, endogenous sucrose content had no correlation with starch content.

\section{The influences of exogenous high sucrose concentration on sugar metabolic enzymes of Solanum tuberosum L. cv. Atlantic in vitro}

The activity of acid invertase in induced cuttings was higher than that in corresponding tubers, and the difference was significant in MS with $80 \mathrm{~g} / \mathrm{l}$ sucrose (Figure 8). With the sucrose concentration increase in MS activity of acid invertase increased in induced cuttings and in tubers individually. Susy and SPS accumulated only in tubers, but no significant differences of Susy and SPS were between $80 \mathrm{~g} / \mathrm{l}$ and $100 \mathrm{~g} / \mathrm{l}$ sucrose (Figure 9).

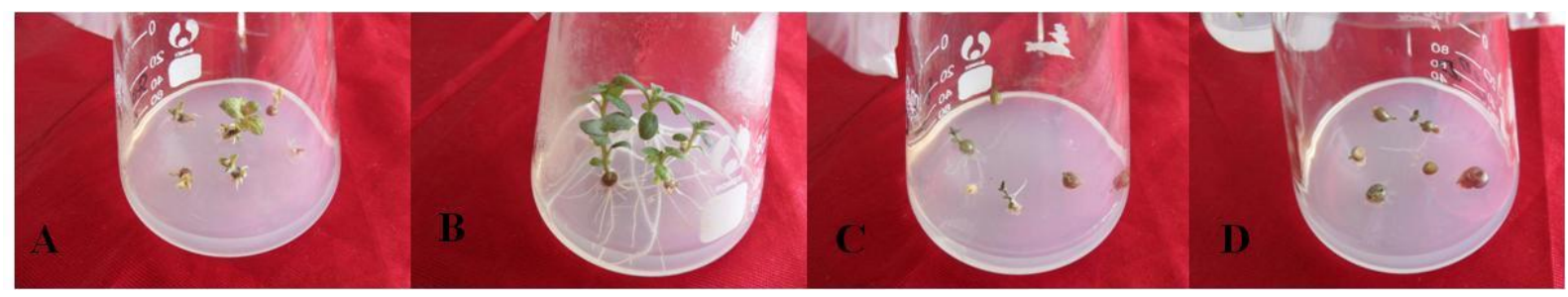

Figure 5. Germination of tubers induced under different conditions in Solanum tuberosum L. cv. Atlantic. A, B: 80 and 100g/l sucrose under 16-h photoperiod; C, D: 80 and 100g/l sucrose under 0-h photoperiod.

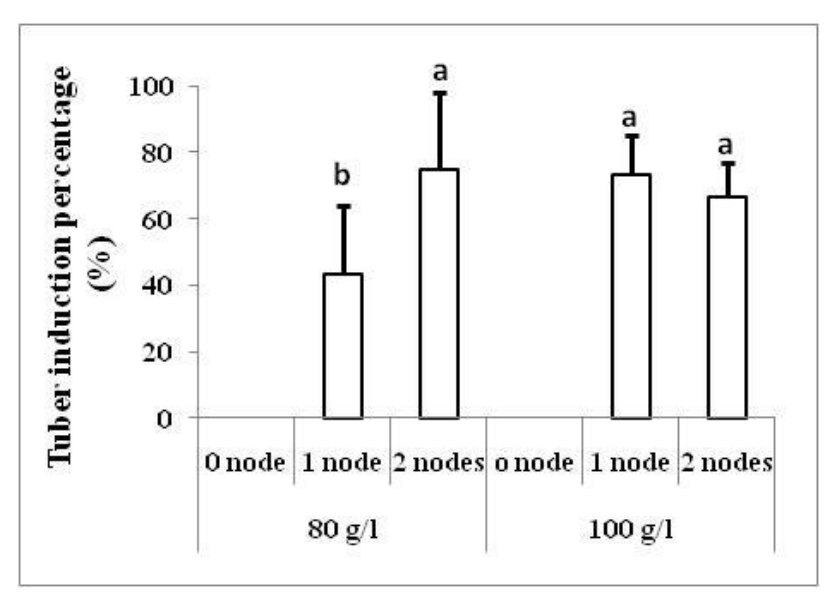

Figure 6. Tuber induction percentage of cutting with different nodes in MS with $80 \mathrm{~g} / 1$ and $100 \mathrm{~g} / \mathrm{l}$ sucrose in Solanum tuberosum L. cv. Atlantic (Same letters indicate no differences within the group at 0.05 level).

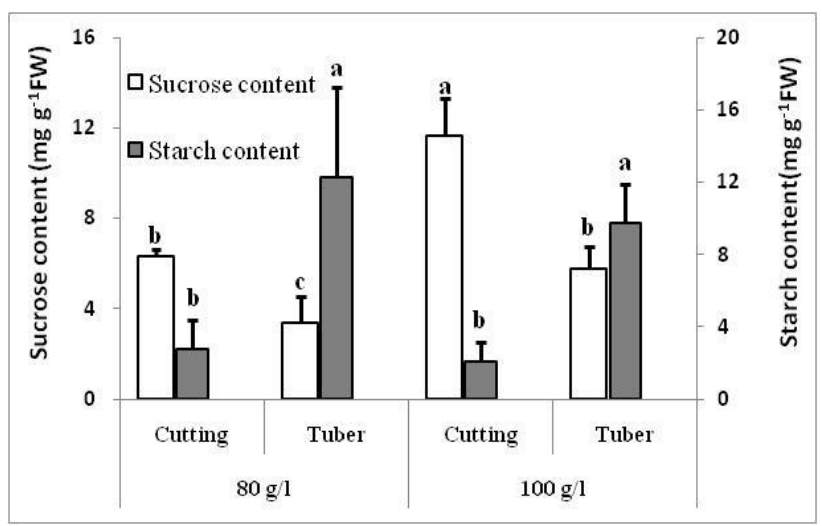

Figure 7. Contents of sucrose and starch of Solanum tuberosum L. cv. Atlantic in MS with $80 \mathrm{~g} / \mathrm{l}$ and $100 \mathrm{~g} / \mathrm{l}$ sucrose (Same letters indicate no differences within the group at 0.05 level). 


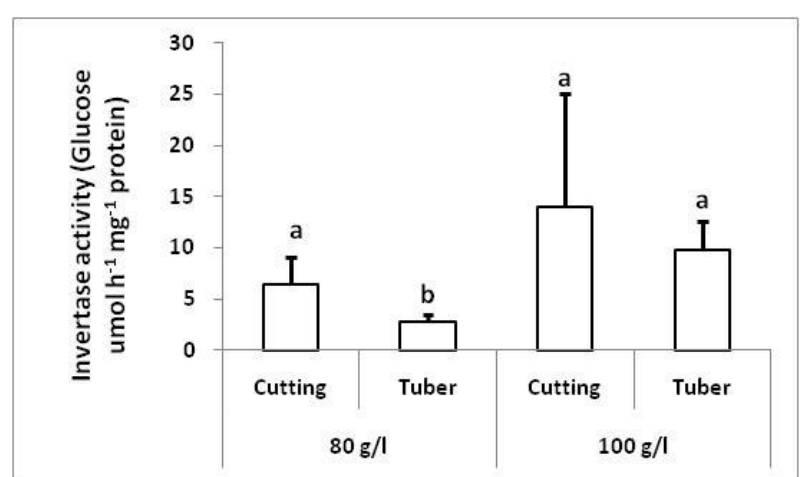

Figure 8. Invertase activity of Solanum tuberosum L. cv. Atlantic in MS with $80 \mathrm{~g} / \mathrm{l}$ and $100 \mathrm{~g} / \mathrm{l}$ sucrose (Same letters indicate no differences within the group at 0.05 level).

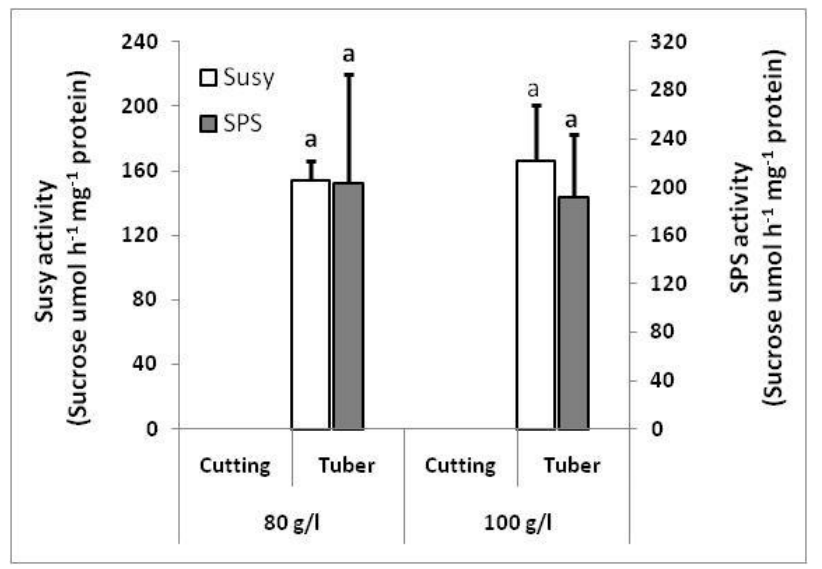

Figure 9. Activities of sucrose synthase and sucrose phosphate of Solanum tuberosum L. cv. Atlantic in MS with $80 \mathrm{~g} / 1$ and $100 \mathrm{~g} / \mathrm{l}$ sucrose (Same letters indicate no differences within the group at 0.05 level).

\section{DISCUSSION}

Potato microtubers produced in vitro are widely used in many areas of agriculture as materials for research (Cenzano et al., 2006, 2008; Gargantini et al., 2009; Raíces et al., 2003a, 2003c; Si et al., 2008). Therefore defining suitable induction factors is very important to in vitro. Nistro et al. (2010) listed high sucrose, short day photoperiod, nitrogen and temperature as the important factors to induce tubers in vitro. Among them Sucrose is considered the most critical stimulus (Ewing \& Struik, 1992; Wang \& Hu, 1982). Some researchers proved that increasing sugar concentrations can promote tuber formation (Raíces et al., 2003b; Simko, 1994; Sonnewald et al., 1997; Xu et al., 1998). The same results were obtained in our study that tubers could be induced by high sucrose ranging from $50 \mathrm{~g} / \mathrm{l}$ to $100 \mathrm{~g} / \mathrm{l}$ and sucrose of 80 and $100 \mathrm{~g} / \mathrm{l}$ could induce more tubers in three cultivars of Solanum tuberosum L. in vitro. For sucrose of $50 \mathrm{~g} / \mathrm{l}$ and $60 \mathrm{~g} / \mathrm{l}$ induced fewer tubers, some researchers combined them with phytohormones to induce more tubers in vitro (Aslam et al., 2011; Ebadi et al., 2011; Hussain et al., 2006; Leclerc et al., 1994).

Potato (Solanum tuberosum L.) tubers are formed under short days, so microtubers are induced under short day or continuous darkness during culture conditions (Altindal \& Karadoğan, 2010; Aslam et al., 2011; Dhital \& Lim, 2012; Hoque, 2010; Hussain et al., 2006; Motallebi-Azar et al., 2013; Servet et al., 2000). Microtubers provided a valuable tool for study of genetic transformation (Gargantini et al., 2009; Si et al., 2008), which was followed by regeneration of plants from in vitro grown microtubers (Ishida et al., 1989). In our study darkness did not significantly improve TIP compared to long-day photoperiods in MS with $80 \mathrm{~g} / \mathrm{l}$ and $100 \mathrm{~g} / \mathrm{l}$ sucrose, but tubers induced under 16-h photoperiod germinated much more than under darkness. It seemed that photoperiods had no dramatic influnece on TIP when exogenous sucrose concentrations ranged from $80 \mathrm{~g} / \mathrm{l}$ to $100 \mathrm{~g} / \mathrm{l}$. The average dormancy duration of microtubers induced in continuous darkness was 210 days, but under 8-h photoperiod it was shortened to 60 days for the same cultivar (Estrada et al., 1986; Tovar et al., 1985). Microtubers produced under light had more number of eyes than those produced in the dark (Gopal \& Minocha, 1998). In our experiment the reasons of higher germinations of tubers induced under 16-h photoperiod might be both. Therefore, tubers induced under 16-h photoperiod will be better to use for further studies.

Nodal section of the shoot or nodal segments/cuttings were used as explants in in vitro tuber induction (Altindal \& Karadoğan, 2010; Aslam et al., 2011; Dhital \& Lim, 2012; Hoque, 2010; Hussain et al., 2006; Motallebi-Azar et al., 2013; Servet et al., 2000). In our work no node no tuber meant that node was very important to tuber induction in MS medium with high sucrose. Although production of potato microtubers in vitro had been studied for a long time, people still keep on trying to look for a simple, speedy and productive induction method (Altindal \& Karadoğan, 2010). Based on our study cutting with no less than 1 node induced by high sucrose could fulfil microtuber production in vitro.

Developing tubers become the largest sinks and a large proportion of sucrose taken up into this sink-tissue was converted to starch during the formation of the potato tuber (Gargantini et al., 2009; Oparka et al., 1990; Prat et al., 1990; Visser et al., 1994; Wright et al, 1989). Khuri \& Moorby (1995) found that the translocation and usage of sucrose was faster than the other sugars in the tubering plantlet in vitro. Starch deposition in potato axillary buds was an indicator of microtuber induction and initiation in a sucrose-containing medium (Berljak \& Pevalek-Kozlina, 1997). In our work high levels of exogenous sucrose resulted in a dramatic high gradient of endogenous sucrose content between induced cuttings and corresponding tubers, which led sucrose to flow. Such flow was beneficial to starch accumulation in tubers in MS with high sucrose. However, high sucrose content did not mean high starch content in tissues.

Sucrose can be degraded by either invertases or Susy in most plants (Koch, 2004; Kruger, 1990). SPS is the plant enzyme thought to play a major role in sucrose biosynthesis. Invertases increased concomitantly with the increase in sugar accumulation in storage tissue (Hatch 
and Glasziou, 1963). But Zhu et al. (1997) got different conclusion that invertase activity had a negative relationship with sucrose accumulation in sugarcane. Our result showed that high content of endogenous sucrose was coordinated with a high activity of invertase during in vitro tuber induction. High sucrose levels increased Susy in potatoes in culture medium (Sowokinos and Varns, 1992). High activity of Susy is found in rapidly growing tissues (Kruger, 1990) and can be used to measure sink strength (Sung et al., 1989). In our study Susy and SPS accumulated only in tubers, but no significant differences between $80 \mathrm{~g} / \mathrm{l}$ and $100 \mathrm{~g} / \mathrm{l}$ sucrose. Therefore sucrose in cuttings was hydrolyzed mainly by invertases but sucrose balance in induced tuber was maintained by Susy and SPS in MS with high level of exogenous sucrose.

In conclusion high levels of exogenous sucrose and nodal cuttings were essential to in vitro tuber induction in potatoes. In the process of induction high levels of exogenous sucrose resulted in differential distribution of sucrose, which triggered differential accumulation of starch and differential activities expression of sugar metabolizing enzymes in cuttings and in corresponding tubers.

\section{ACKNOWLEDGMENT}

This research was supported financially by China Agricultural Industry Technology System (CARS-10). We are grateful to Dr. Gülden Haspolat, of the Aegean Agricultural Research Institute, Department of Horticulture-Ornamental Plant, for her modification and advices.

\section{LITERATURE CITED}

Altindal, D. and T. Karadogan. 2010. The effect of carbon sources on in vitro microtuberization of potato (Solanum tuberosum L.). Turk. J. Field Crops, 15(1): 7-11.

Aslam, A., A. Ali , N.H. Naveed, A. Saleem, J. Iqbal and A. Aslam. 2011. Effect of interaction of 6-benzyl aminopurine (BA) and sucrose for efficient microtuberization of two elite potato (Solanum tuberosum L.) cultivars, Desiree and Cardinal. Afr. J. Biotechnol. 10(59):12738-12744.

Avigad, C. 1982. Sucrose and other dissaccharides. In: Storage Carbohydrates in Vascular Plants, ed. Lewis D.H., 53-73, Cambridge University Press, Cambridge.

Barker, W.G. 1953. A method for the in vitro culturing of potato tubers. Sci. 118:384-385.

Berljak, J. and B. Pevalek-Kozlina. 1997. Starch accumulation as a marker for microtuberization in potato (Solanum tuberosum). Biologia, 52(4):553-559.

Bradford, M.M. 1976. A rapid and sensitive method for the quantitation of microgram quantities of protein utilizing the principle of protein-dye binding. Anal. Biochem. 72: 248-254.

Cenzano, A., A. Vigliocco, O. Miersch and G. Abdala. 2006. Octadecanoid levels during stolon to tuber transition in potato. Potato Res. 48:107-115.

Cenzano, A., R. Cantoro, G. Racagni, C.D.L. Santos-Briones, T. Hernández-Sotomayor and G. Abdala. 2008. Phospholipid and phospholipase changes by jasmonic acid during stolon to tuber transition of potato. Plant Growth Regul. 56(3):307-316.
Davies, H.V. 1984. Sugar metabolism in the stolon tips of potato during tuberization. Zei tsehrift für Pflanzenphysiologie, 113 377-381.

Dhital, S. P. and H. T. Lim. 2012. Microtuberization of potato (Solanum tuberosum L.) as influenced by supplementary nutrients, plant growth regulators, and in vitro culture conditions. Potato Res. 55(2):97-108.

Ebadi, M. and A. Iranbakhsh. 2011. The induction and growth of potato (Solanum tuberosum. L) microtubers (santé cultivar) in response to the different concentrations of 6-benzylaminopurine and sucrose. Afr. J. Biotechnol. 10(52):10626-10635.

Estrada, R., P. Tovar, and J. H. Dodds. 1986. Induction of in vitro tuber in a broad range of potato genotypes. Plant Cell Tissue Organ Cult. 7:3-10.

Ewing, E.E and P.C. Struik. 1992. Tuber formation in potato: induction, initiation and growth. In: Horticultural Review, ed. Janick J., 89-198, John Wiley \& Sons Inc., New York.

Gargantini, P.R., V. Giammari, C. Grandellis, S.E. Feingold, S. Maldonado and R.M. Ulloa. 2009. Genomic and functional characterization of stCDPK1. Plant Mol. Biol. 70(1-2):153-172.

Geigenberger, P. and M. Stitt. 1993. Sucrose synthase catalyses a readily reversible reaction in vivo in developing potato tubers and other plant tissues. Planta, 189: 329-339.

Gopal, J. and J.L. Minocha. 1998. Effectiveness of in vitro selection for agronomic characters in potato. Euphytica, 103:67-74.

Hatch, M.D. and K.T. Glasziou. 1963. Sugar accumulation cycle in sugar cane. II. relationship of invertase activity to sugar content \& growth rate in storage tissue of plants grown in controlled environments. Plant Physiol. 38(3):344-348.

Hoque, M.E. 2010. In vitro tuberization in potato (Solanum tuberosum L.). Plant omics J. 3(1):7-11.

Hovenkamp-Hermelink, J.H.M., J.N.D. Vries, P. Adamse, E. Jacobsen, B. Witholt and W.J. Feenstra. 1988. Rapid estimation of the amylase/amylopectin ratio in small amounts of tuber and leaf tissue of the potato. Potato Res. $31: 241-246$

Hussain, I., Z. Chaudhry, A. Muhammad, R. Asghar, S.M. Saqlan, and H. Rashid. 2006. Effect of chlorocholine chloride, sucrose and BAP on in vitro tuberization in potato (Solanum tuberosum L. cv. Cardinal). Pak. J. of Bot. 38(2): 275-282.

Ishida, B.K., G.W. Snyder and W.R. Belknap. 1989. The use of in vitro-grown microtuber discs in Agrobacterium-mediated transformation of Russet Burbank and Lemhi Russet potatoes. Plant Cell Rep. 8(6):325-328.

Khuri, S. and J. Moorby. 1995. Investigations into the role of sucrose in potato cv. Estima microtubers production in vitro. Ann Bot. 75: 295-303.

Koch, K. 2004. Sucrose metabolism: regulatory mechanisms and pivotal roles in sugar sensing and plant development. Curr. Opin Plant Biol. 7(3):235-246.

Kruger, N.J. 1990. Carbohydrate synthesis and degradation. In: Plant physiology, biochemistry and molecular biology, ed. Dennis D.T. \& Turpin D.M., 59-76, Longman, Harlow.

Leclerc, Y., D.J. Donnelly and J.E.A. Seabrook. 1994. Microtuberization of layered shoots and nodal cuttings of potato: The influence of growth regulators and incubation periods. Plant Cell Tissue Organ Cult. 37(2):113-120.

Lizarrage, R., Z. Huaman and J.H. Dodds. 1989. In vitro conservation of potato germplasm at the International Potato Center. Am. Potato J. 66:253-269.

Morell, M. and L. Copeland. 1985. Sucrose synthase of soybean nodules. Plant Physiol. 78, 149-154 
Motallebi-Azar, A., S. Kazemiani and F. Yarmohamadi. 2013. Effect of sugar/osmotica levels on in vitro microtuberization of potato (Solanum tuberosum L.). Russian Agricul. Sci. 39(2): 112-116.

Nistor, A., G. Campeanu, N. Atanasiu,, Chiru, N. and D. Karácsonyi. 2010. Influence of genotype on microtuber production. Notulae Botanicae Horti Agrobotanici Cluj-Napoca, 38(1):209-212.

Oparka, K.J., H.V. Davies, K.M. Wright, R. Viola and D.A.M Prior. 1990. Effect of sink isolation on sugar uptake and starch synthesis by potato-tuber storage parenchyma. Planta, 182:113-117.

Öztürk, G. and Z. Yildirim. 2010. A comparison of field performances of minitubers and microtubers used in seed potato production. Turk. J. Field Crops, 15(2): 141-147.

Prat, S., W.B. Frommer, M.R. Höfgen, M. Keil, M. Köster-Töpfer, X.J. Liu, B. Müller, H. Peña-Cortés, M. Rocha-Sosa, J.J. Sanchez-Serrano, U. Sonnewald and L. Willmitzer. 1990. Gene expression during tuber development in potato plants. FEBS Lett. 268:334-338.

Raíces, M., P.R. Gargantini, D. Chinchilla, M. Crespi, M.T Téllez-Iñón and R.M. Ulloa. 2003a. Regulation of CDPK isoforms during tuber development. Plant Mol. Biol. 52(5): 1011-1024.

Raíces, M., G.C. MacIntosh, R.M. Ulloa, P.R. Gargantini, N.F. Vozza and M.T. Tellez-Iňón. 2003b. Sucrose increases calcium-dependent protein kinase and phosphatase activities in potato plants. Cell. Mol. Biol. 49:959-964.

Raíces, M., R.M. Ulloa, G.C. Macintosh, M. Crespi and M.T. Téllez-Iñón. 2003c. StCDPK1 is expressed in potato stolon tips and is induced by high sucrose concentration. J. Exp. Bot. 54(392): 2589-2591.

Servet, K., D.P. Alexander, E.R. Paul and D.K. Stephen. 2000. Comparison of thidiazuron and two nitroguanidines to kinetin on potato microtuberization in vitro under short and long days. J. Plant Growth Regul.19:429-436.

Si, H.J., J. Liu, J. Huang and C.H. Xie. 2008. Functional analysis of a class I patatin gene $S K 24-1$ in microtuber formation of transgenic potatoes. Can. J. Plant Sci. 88(4):593-598.
Simko, I. 1994. Sucrose application causes hormonal changes associated with potato tuber induction. J. Plant Growth Regul, 13:73-77.

Sonnewald, U., M.R. Hajirezael, J. Kossman, A. Heyer, R.N. Trethewey and L. Willmitzer. 1997. Increased potato tuber size resulting from apoplastic expression of a yeast invertase. Nat. Biotechnol. 15:794-797.

Sowokinos, J.R. and J.L. Varn. 1992. Induction of sucrose synthase in potato tissue culture: effect of carbon source and metabolic regulators on sink strength. J. Plant Physiol. 139(6):672-679.

Sung, S.S., W.P. Xu and C.C.J. Black. 1989. Identification of actively filling sucrose sinks. Plant Physiol. 89, 1117-1121.

Tovar, P., R. Estrada, L. Schilde-Rentschler, and J.H. Dodds. 1985. Induction of in vitro potato tubers. CIP circular 13:1-4, International Potato Centre, Lima.

Visser, R.G.F., D. Vreugdenhil, T. Hendriks and E.J. Jacobsen. 1994. Gene expression and carbohydrate content during stolon to tuber transition in potatoes (Solanum tuberosum). Physiol. Plant. 90:285-292.

Wang, P. and C. Hu. 1982. In vitro tuberization and virus free seed-potato production in Taiwan. Am. Potato J. 59: 33-37.

Wang, W. 2000. Using phenol method to determine sucrose content in plant. In: Experiment principle and technique for plant physiology and biochemistry, ed. Li, H.S., 199-200, China Higher Education Press, Beijing.

Wright, K.M. and K.J. Oparka. 1989. Sucrose uptake and partitioning in discs derived from source versus sink potato tubers. Planta, 177(2): 237-244.

Xu, X., A.A. M. van Lammeren, E. Vermeer and D. Vreugdenhil. 1998. The role of gibberellln, abscisic acid, and sucrose in the regulation of potato tuber formation in vitro. Plant Physiol. 117:575-584.

Zhu, Y.J., E. Komor, and P.H. Moore. 1997. Sucrose Accumulation in the sugarcane stem is regulated by the difference between the activities of soluble acid invertase and sucrose phosphate synthase. Plant Physiol., 115(2):609-616. 